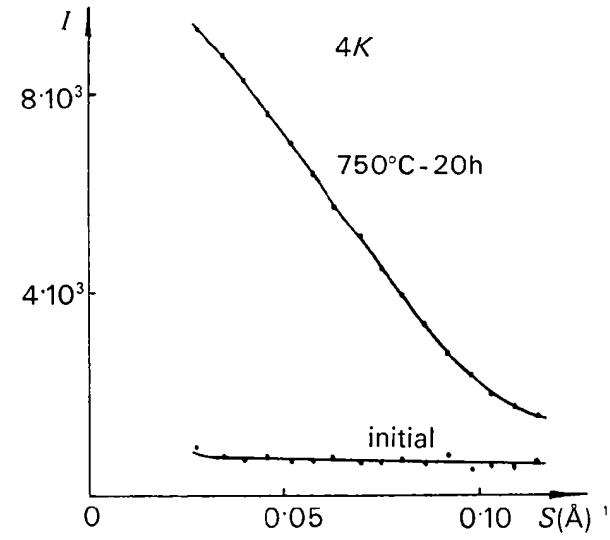

Fig. 7. The SAS curves for the specimen $4 K$ in the initial state and after annealing $750^{\circ}-20 \mathrm{~h}$.

regations in the glassy state. In association with X-ray SAS it is the main source of quantitative information about the kinetics of these processes in their initial stages.

\section{References}

Berezhnoy, A. Y. (1966). Sitallei photositalli, pp. 68-76. Moskva: Mashinostroenie.

Gaganov, D. A. \& Poray-Koshits, E. A. (1965). Strukturnie prevrascheniya v steklakh pri porishennikh temperaturakh. pp. 100-109. Moskva-Leningrad: Nauka.

MCMillan, P. W. (1967). Steklokeramika, pp. 79-82. Moskva: Mir.

Maurer, R. D. (1962). J. Appl. Phys. 33, 2132-2139.

Pavlushinin, N. M. \& Khodakovskaya, R. Y. Stecloobraznoe sostoyanie p. 66-69. Moskva-Leningrad: Nauka.

Pavlushin, N. M. \& Khodakovskaya, R. Y. (1971). Izi. Akad. Nauk SSSR, Ser. Neorg. Mater. 7, 846-849.

Roy, R. (1960). J. Amer. Ceram. Soc. 43, 670-671.

Schedrin, B. M. \& FEYGIN, L. A. (1966). Kristallografiya, 11, 159-163.

STOOKEY, S. D. (1959). Glastechn. Ber. 32K, (5), V/1-V/8.

Symposium on Nucleation and Cristallization in Glasses and Melts (1962). pp. 5-9. Ohio: Amer. Ceram. Soc.

Tomozava, M., Herman, H. \& MacCrone, R. K. (1970).

Phys. Chem. Glass, 11, 136-140.

Zener, C. (1949). J. Appl. Phys. 20, 950-953.

J. Appl. Cryst. (1974). 7, 210

\title{
The Study of Inhomogeneities in Solid Solutions
}

\author{
BY V. GEROLD \\ Max-Planck-Institut für Metallforschung, Stuttgart, Germany (BRD)
}

\begin{abstract}
Three primary investigation techniques are useful for studying clusters or small particles in solid solution: X-ray small-angle scattering, neutron small-angle scattering, and transmission electron microscopy. Advantages and disadvantages of these methods will be discussed. Combined usage, as for example $\mathrm{X}$-ray and neutron small-angle scattering, to obtain additional information will be considered, and preliminary results on the $\mathrm{Zn}$ and $\mathrm{Mg}$ content of small G.P. zones in $\mathrm{Al}-\mathrm{Zn}-\mathrm{Mg}$ alloys will be presented. Examples are given where the use of X-ray small-angle scattering has led to further understanding of the nucleation and precipitation phenomena in the alloy systems: $\mathrm{Ti}-\mathrm{Mo}, \mathrm{Al}-\mathrm{Zn}-\mathrm{Mg}, \mathrm{Al}-\mathrm{Ge}$, and Al-In. The primary information is supplemented by results from physical-property measurements. For instance, the resistivity changes of Al-Ge during nucleation of Ge clusters could be interpreted quantitatively and confirmed the model used for analysing the X-ray data. SAS results on age-hardenable alloys help the understanding of mechanical properties in the early stages of precipitation.
\end{abstract}

